\title{
Upregulation of Tissue Transglutaminase in Transforming Growth Factor- $\beta$ Induced Epithelial Mesenchymal TG2Transdifferentiation In Rat Tubular Epithelial Cells
}

\author{
SANAA FADEL, Ph.D.** and RACHEL EMMA, M.D.* \\ Sheffield Kidney Institute, University of Sheffield, Sheffield* and The Department of Microbiology, Faculty of Pharmacy, \\ Cairo University, Cairo, Egypt**
}

\begin{abstract}
Background: Epithelial-Mesenchymal Transdifferentiation (EMT) is believed to be a key step in the course of glomerular and tubulointerstitial fibrosis. Many of the regulators of this process have been identified and Transforming Growth Factor$\beta$ (TGF- $\beta$ ) plays a central role. Tissue transglutaminase (TG2) has a crucial role in extracellular matrix formation and stabilization.
\end{abstract}

Aim of Study: This study was designed to explore whether TG2 is essential in EMT induced by TGF- $\beta$ in renal tubular epithelial cells.

Material and Methods: EMT was achieved by treating NRK52-E renal tubular epithelial cells with high concentration of rhTGF- $\beta(10 \mathrm{ng} / \mathrm{ml})$ for 24,48 and $72 \mathrm{~h}$. Development of mesenchymal cell markers Fibroblast Specific Protein (FSP$1)$ and $\alpha$ Smooth Muscle Actin ( $\alpha$-SMA) and decrease in tubular epithelial cell surface marker E-Cadherin were used to confirm EMT. The NTU283; TG2 inhibitor was used for the inhibition assays. TG2 activity was quantified using a 14C putrescine incorporation assay. Protein expression and localisation of different markers were assessed by western blot and immunofluorescent dual immunofluorescent staining. Phase analysis was used to quantify the amount of staining for each of the markers used.

Results: A significant increase in TG2 activity and protein expression were both observed with TGF- $\beta$ induced transdifferentiation at $48 \mathrm{~h}$. This observation was associated with loss of epithelial cell marker E-Cadherin and appearance of intracellular $\alpha$-SMA and FSP-1, characteristic of myofibroblasts. Dual staining showed high TG2 levels in cells $(0.254 \pm 0.07)$, compared to the control $(0.02 \pm 0.008)$. This also showed loss of epithelial phenotype, decrease of E-cadherin and acquisition of myofibroblast characteristics $\alpha$-SMA $(0.671 \pm 0.13)$ compared to the control $(0.076 \pm 0.016)$ and FSP-1 $(0.492 \pm 0.017)$ compared to control $(0.03 \pm 0.017)$. Cells also demonstrated high degree of co-localization of Collagen I (ColI) and $\alpha$ SMA with TG2. The NTU283; TG2 inhibitor ameliorated TGF- $\beta$ induced EMT. This was also associated with changed pattern of collagen I and $\alpha$-SMA co-localization.

Conclusion: This data demonstrated upregulation of TG2 during the process of TGF- $\beta$ induced EMT. TG 2 inhibitor

Correspondence to: Dr. Sanaa Fadel,

E-Mail: sanfadel@gmail.com showed non-significant reduction of both TG2 and mesenchymal markers but demonstrated changes in the molecular configuration of mesenchymal markers $\alpha$-SMA and Col I, raising the possibility of a role of TG2 in EMT.

Key Words: TG2 - Epithelial-mesenchymal transformation $E M T$ - Transforming growth factor $-\leq 1(T G F-\leq 1)$ - CKD - Renal fibrosis.

\section{Introduction}

MESENCHYMAL transformation of tubular epithelial cells into myofibroblastic phenotype in response to kidney injury plays a crucial role in the initiation and progression of kidney fibrosis [1]. EMT is regulated by growth factors and cytokines. The growth factor TGF- $\beta 1$ has a central role in this process and is thought to be the major growth factor initiating EMT [2-4]. TG2 belongs to family of transglutaminase enzymes that catalyse the covalent crosslinking of proteins by formation of new iso-di peptide bonds. This multifunctional protein is involved in a variety of biological processes, including cell differentiation, death, inflammation, migration, and tissue fibrosis [5] . Transamidating activity of TG2 has a tumor-suppressive function in healthy cells by stabilizing Extracellular Matrix (ECM), but an oncogenic potential in malignant cells [6]. The expression level of TGM2 was 25 -fold higher in tumorigenic cells than nontumorigenic cells [7]. Their work further revealed that knockdown of TGM2 inhibited cell metastatic abilities by down-regulating $\mathrm{N}$-cadherin and vimentin and up-regulating E-cadherin.

It has been shown that aberrant expression of TG2 is associated with loss of epithelial cell marker E-cadherin and upregulation of mesenchymal cell markers, such as fibronectin, vimentin, $\mathrm{N}$-cadherin in the course of EMT [8]. TG2 is also known to stimulate tissue fibrosis through TGF- $\beta$ activation. 
In TG2 knockout mice, free active TGF- (3 was significantly decreased compared to wild type mice in response to ureteric obstruction [9]. Whether this effect on tissue fibrosis is mediated through EMT or not is unclear. It has long been recognised that TG2 plays a key role in the crosslinking of the TGF-( 31 latent complex to the ECM. Such a TG2-mediated binding is a key step in the exposure of TGF-( 31 to proteolytic enzymes and its activation [10].

Elevated TG2 expression has been strongly associated with RCC progression in terms of cell survival, invasion and migration [11]. More interestingly, Nyabam et al., [12] showed that increased TG2 expression in normal and cystic fibrosis bronchial epithelial cells increased TGF $(31$ levels, promoting EMT progression, and suggested TG2 may provide a potential prognostic and therapeutic tool.

This work aims to study the role of TG2 in TGF- $(3$ induced renal EMT and explores whether TG2 is upregulated in the course of this process. We also explored the effect of inhibition of TG2.

\section{Material and Methods}

This study was conducted in Sep. 2017 in Sheffield Kidney Institute, University of Sheffield, UK.

Cell culture and TGF-( 3 treatment: The wellcharacterised normal rat kidney epithelial cell line NRK52E (American type Culture collection) were used to asses EMT. NRK52E cells were grown in DMEM containing 1\% L-Glutamine and supplemented with 5\% FCS and $1 \%$ antibiotic/ antimycotic solution (Invitrogen, Burlington, ON). Cells were grown to $80 \%$ confluency, serum starved for $24 \mathrm{~h}$ and treated with $10 \mathrm{ng} / \mathrm{ml}$ rhTGF-(3 (R \& D Systems) for $72 \mathrm{~h}$.

Immunofluorescent staining: Immunofluorescent staining was performed using established procedures on epithelial cells cultured on coverslips. Briefly, control and TGF- (3 stimulated NRK52E cells were washed in Phosphate-Buffered Saline (PBS) three times and fixed in ice cold methanol acetone $(7: 3)$ for $10 \mathrm{~min}$. The cells were allowed to air dry for $10 \mathrm{~min}$ and either stored at $-20^{\circ} \mathrm{C}$ or rehydrated for 10min in PBS. Coverslips where then blocked in 5\% BSA for $15 \mathrm{~min}$ and washed in PBS. Cells where incubated with primary antibodies, which was either monoclonal anti-E-Cadherin (1:100, BD Transduction Laboratories), monoclonal anti- $\alpha$-SMA clone 1A4 (1:100, Sigma-Aldrich), Polyclonal anti-FSP 1 (1:200, S $100 A 4$, Dako), Monoclonal anti-TG Antibody (1:100 Transglutaminase II Ab-2 Clone TG100, Thermo Scientific) or monoclonal antibody to Collagen I (1:100, Abcam). This was incubated overnight at $4^{\circ} \mathrm{C}$. Coverslips where then washed and incubated with the appropriate secondary FITC-conjugated antibody.

Dual staining was performed using an initial incubation with a primary antibody overnight at $4^{\circ} \mathrm{C}$. Coverslips where then washed and incubated with the appropriate secondary FITC-conjugated antibody. This was followed by washing and incubation with a TxRed-conjugated primary antibody overnight at $4^{\circ} \mathrm{C}$. Coverslips where then washed and incubated with the appropriate secondary TxRed-conjugated antibody for $1 \mathrm{~h}$ at RT. Negative controls for all antibodies included incubation of sections with serum without induction with TGF(31.

Transglutaminase activity: Treated NRK52E cells were removed with $1 \mathrm{x}$ trypsin EDTA and centrifuged at $800 \mathrm{rpm}$ for $5 \mathrm{~min}$. The resultant pellet was washed with PBS and cells were resuspended in $100 \propto 1$ of STE buffer $(0.32 \mathrm{M}$ sucrose, $5 \mathrm{mM}$ Tris, $1 \mathrm{mM}$ EDTA) containing protease inhibitors phenylmethylsulfonyl fluoride $(1 \mathrm{mM})$, benzamidine $(5 \mathrm{mM})$ and leupeptin $(10 \propto \mathrm{g} / \mathrm{ml})$. Transglutaminase activity was then determined by the $\mathrm{Ca}^{2}+$-dependent incorporation of $\left[1,4-{ }^{14} \mathrm{C}\right] \mathrm{pu}-$ trescine (Amersham, Biosciences) into N, N'dimethylcasein as previously described [13]. Results were corrected to units/mg of protein (1 unit equals $1 \mathrm{nmol}$ of putrescine incorporated per hour at $37^{\circ} \mathrm{C}$ ).

Western blot: NRK52E cells were lysed in buffer containing $50 \mathrm{mM}$ Tris, $0.14 \mathrm{M} \mathrm{NaCl}, 0.4 \%$ Triton X-100 and mini protease inhibitor tablet (Roche). Protein concentrations were determined using a protein kit based on the lowry method (Bio-Rad). Twenty mg of protein was separated on a 7.5\% SDS- polyacrylamide gel and the proteins electrotransferred to a nitrocellulose membrane. Membranes were blocked in 10\% skimmed milk and primary antibody was added i.e. anti-TG2, anti-E-Cadherin (Transduction Laboratories, KY) and anti- $\alpha$-SMA (Sigma-Aldrich, UK) at concentration of 1:100, 1:250 and 1:500 respectively in $5 \%$ milk/TBST O/N at $4^{\circ} \mathrm{C}$. Membranes were washed in TBST for 5 minutes for 3 washes. Secondary antibody was added 1:20,000 in 5\% milk/TBST for $1 \mathrm{~h}$. The membranes were washed as previously and the signal was visualised by enhanced chemiluminescence system (ECL, Amersham).

Transglutaminase inhibitor NTU283: NRK52E cells were grown in 6 well plates until $80 \%$ confluency was achieved. Cells were serum starved 
for $24 \mathrm{~h}$ and pre-treated with the TG2 inhibitor NTU283 (400 M) for 2h. Cells were then stimulated with TGF- $\beta(10 \mathrm{ng} / \mathrm{ml})$ for $72 \mathrm{~h}$. A TG2 activity assay was performed and cell surface examination using immunofluorescent dual staining.

\section{Statistical analysis:}

Results are expressed as mean \pm Standard Deviation (SD). Statistical difference was assessed by Analysis of Variance (ANOVA) followed by $t$ test or Mann-Whitney U depending on data distribution. A $p$-value $<0.05$ was considered to be significant.

\section{Results}

Phase contrast microscopy showed morphological changes in NRK52E cells following TGF- $\beta$ treatment. Fig. (1A) demonstrates that NRK52E produced classical epithelial cobble stone morphology. When induced with TGF- $\beta$ for $72 \mathrm{~h}$, there was some cell loss, while remaining cells demonstrated spindle fibroblast-like morphology (1B). In parallel, induced cells displayed a marked reduction in the epithelial marker E-Cadherin shown by immunofluorescent staining $(1 \mathrm{C}, \mathrm{D})$ and western blot analysis ( $86 \%$ reduction, compared to control). Western blot also demonstrated an increase in the expression of $\alpha$-SMA ( $600 \%$ increase, in comparison to control). An increase in TG2 enzyme expression was shown over $72 \mathrm{~h}$ (over double the amount produced in control). This was associated with a significant increase in TG2 activity as assessed by putrescine incorporation assay. Results were taken from three independent experiments (data not shown).
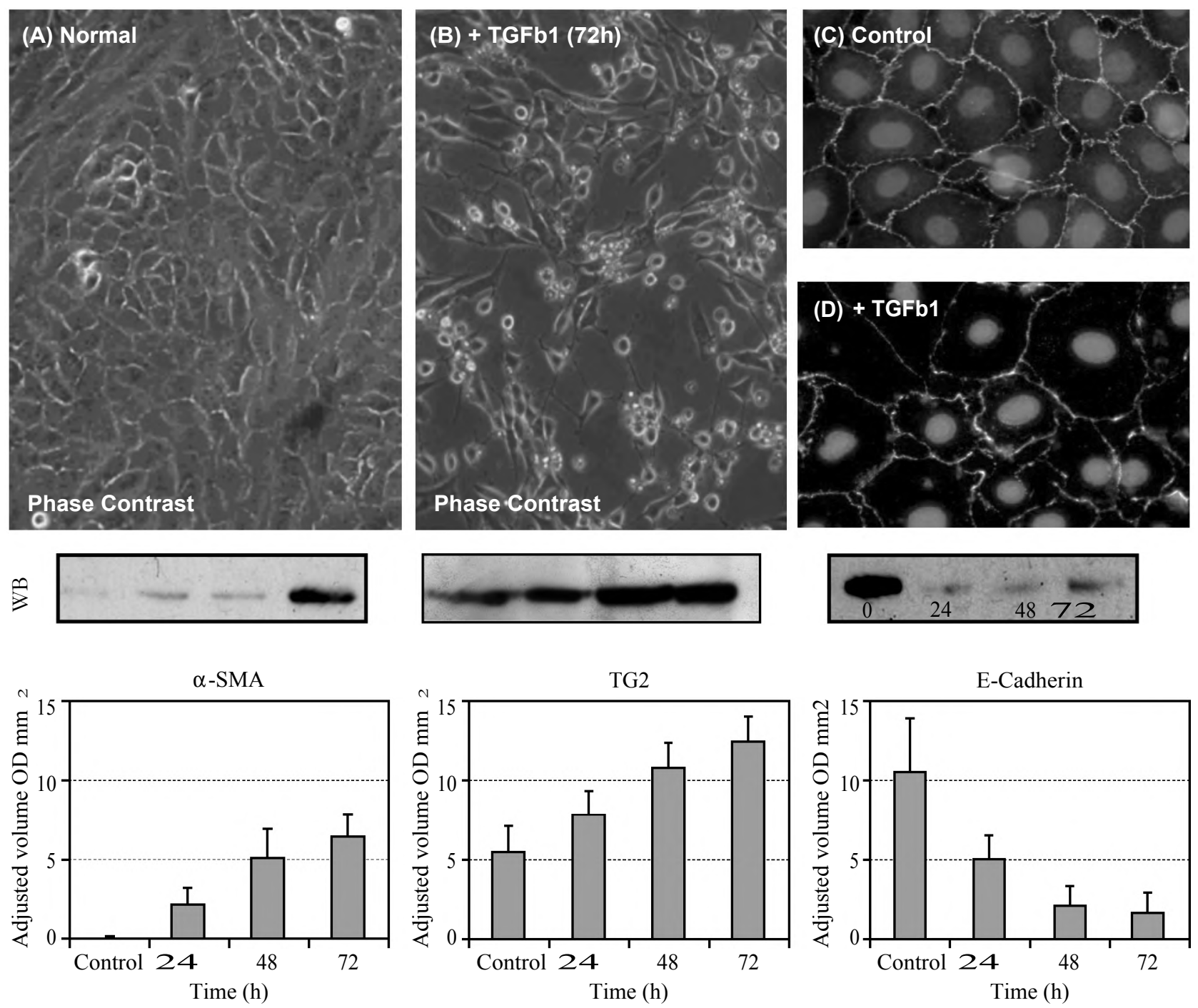

Fig. (1): Morphological changes in NRK52E following TGF- $\beta$ treatment. (A) Control NRK52E cells. (B) NRK52E cells induced with TGF- $\beta(10 \mathrm{ng} / \mathrm{ml})$ for $72 \mathrm{~h}$. (C, D) Assessment of E-Cadherin using immunoflurescent staining and western blotting. Western blotting was also used to quantify the change of SMA and TG2. Results are expressed as adjusted volume $\mathrm{ODmm}^{2}$ taken from three independent experiments $\pm \operatorname{SEM}(* p<0.05)$. 
Dual immunofluorescent staining was used to examine the increase of FSP1 and $\alpha$-SMA in fibroblasts, and detect their co-localization. Induction with $10 \mathrm{ng} / \mathrm{ml}$ of TGF- $\beta$ revealed a marked increase of FSP-1 Fig. (2D), in comparison to control Fig. (2A). This showed a typical pattern of FSP-1 staining widely diffused in the cytoplasm and found to be statistically significant $(p<0.05)$ Fig. (5A). Alpha-SMA considerably increased upon stimulation with TGF- $\beta(p<0.001)$ Fig. (5B), with most of positive $\alpha$-SMA showing typical fibril structure Fig. (2E). Double staining revealed that FSP1 colocalized with $\alpha$-SMA in most fibroblasts Figs.
$(2 \mathrm{~F}, 6 \mathrm{~A})$, with more than $60 \%$ of the total cells colocalised, compared to only $5 \%$ in the control cells $(p<0.001)$. Treatment with NTU 283 inhibitor did not really affect degree of co-localisation Fig. (2I), but showed a change of the distribution of FSP-1 in the cells, being focused at certain points at the cells rather than homogenously distributed Fig. (2G). FSP-1 showed only $20 \%$ decrease, which was found to be non significant ( $p>0.05)$ Fig. (5A). Alpha-SMA also showed no significant decrease Fig. (5B). However, the structure of fibrils largely deteriorated, and most of $\alpha$-SMA lost the typical fibril structure Fig. (2H).
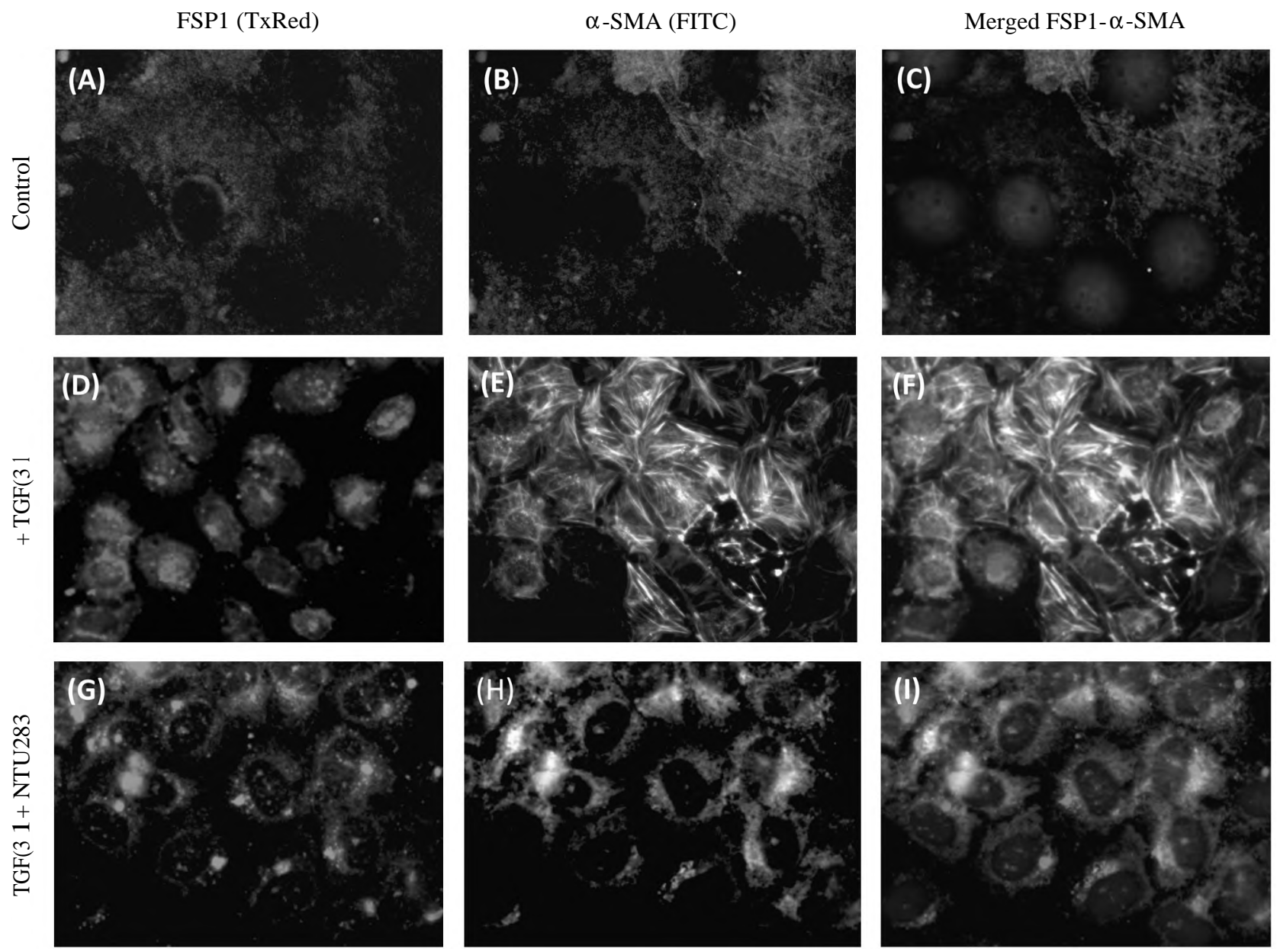

Fig. (2): Dual immunofluorescent staining of $\alpha$-SMA and FSP1 in NRK52E cells treated with TGF- $\beta$. NRK52E cells were treated with TGF- $\beta(10 \mathrm{ng} / \mathrm{ml})$ for $72 \mathrm{~h}$. Cells were initially stained with anti- $\alpha$-SMA antibody conjugated to FITC and then repeat staining performed using an anti-FSP1 antibody and a secondary antibody conjugated to TxRed. Another experiment was performed following addition of 400 MM of NTU 283 inhibitor. Magnification 400x.

Dual staining was also used to examine the change of shape and quantity of TG2 and $\alpha$-SMA, and their co-localization. This denoted an increase in the amount of TG2 $(p<0.01)$ Figs. (3D, 5D), and $\alpha$-SMA $(p<0.001)$ Figs. $(3 \mathrm{E}, 5 \mathrm{~B})$. Most of TG2 positive cells showed co-localisation with $\alpha$ -
SMA, which was found highly significant ( $p$ $<0.001)$ Figs. (3F, 6B). The distribution of TG2 showed a homogenous pattern around the cells. Treatment with NTU 283 inhibitor had some inhibitory effect on TG2 Fig. (3G), which was found to be non-significant Fig. (5D). However, the 
distribution changed and was mainly focused at one point over the nucleus.

The same staining technique showed that COLI and $\alpha$-SMA exhibited a considerable increase in the amount of COLI Fig. (4D), with most of COLI localized around the nucleus. Only occasional COLI was expressed in normal kidney tissue Fig.
(4A). Co-localisation could be seen in around $70 \%$ Fig. (4F) and found to be highly significant Fig. (6C). Upon treatment with NTU 283 inhibitor, the amount of neither $\alpha$-SMA nor COLI was significantly affected $(p>0.05)$ Fig. $(5 \mathrm{~B}, \mathrm{C})$, but it demonstrated a change of COLI distribution, which was mainly pushed away towards the nucleus Fig. $(4 \mathrm{G}, \mathrm{I})$.
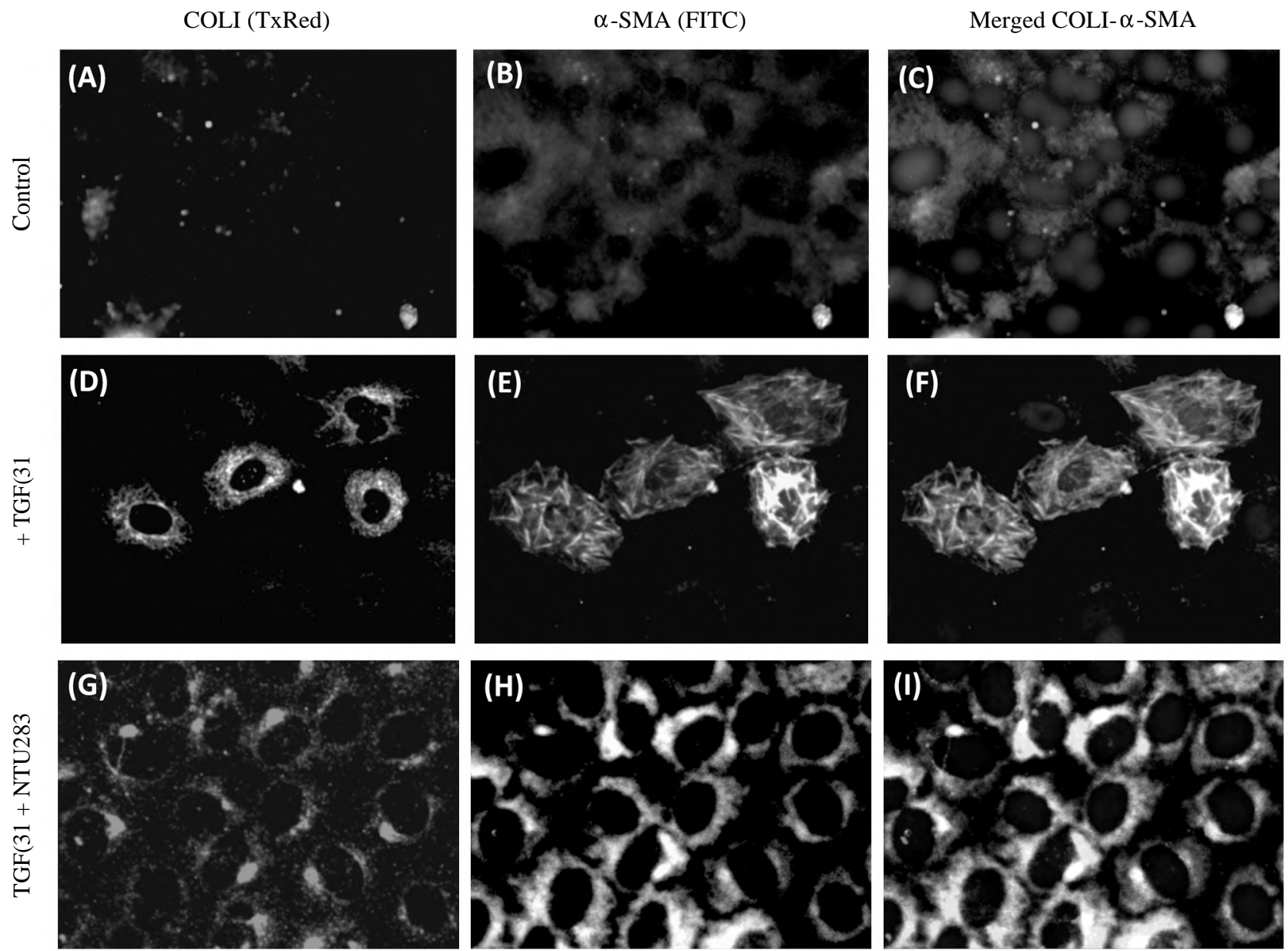

Fig. (3): Dual immunofluorescent staining of $\alpha$-SMA and TG2 in NRK52E cells treated with TGF- $\beta$. NRK52E cells were treated with TGF- $\beta(10 \mathrm{ng} / \mathrm{ml})$ for $72 \mathrm{~h}$. Cells were initially stained with anti- $\alpha$-SMA antibody conjugated to FITC and then repeat staining performed using an anti-Tg antibody and a secondary antibody conjugated to TxRed. Another experiment was performed following addition of 400 MMof NTU 283 inhibitor. Magnification 400x.

COLI (TxRed)

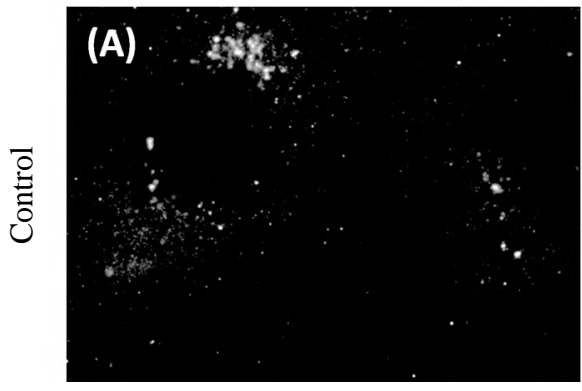

$\alpha$-SMA (FITC)

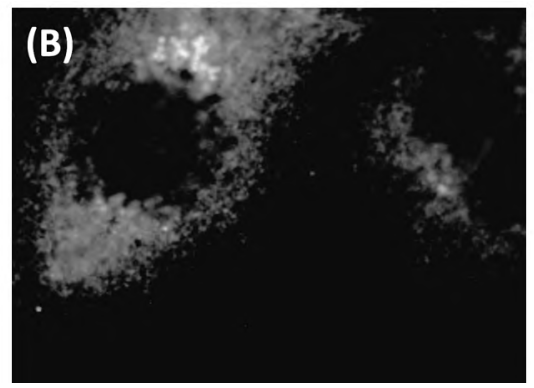

Merged COLI- $\alpha$-SMA

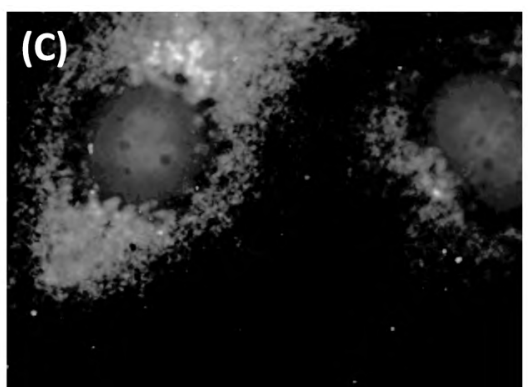



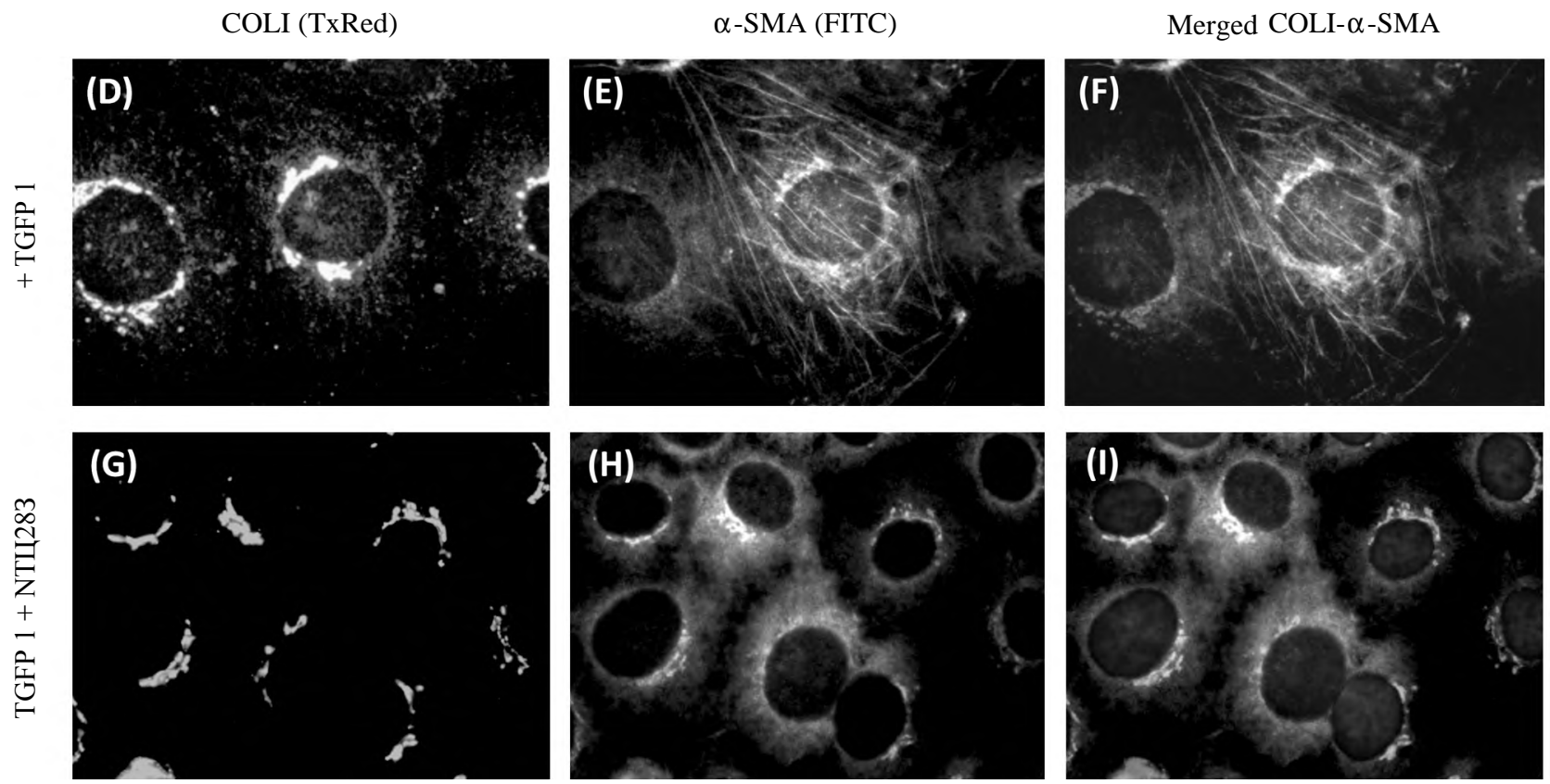

Fig. (4): Dual immunofluorescent staining of $\alpha$-SMA and COLI in NRK52E cells treated with TGF- $\beta$. NRK52E cells were treated with TGF- $\beta(10 \mathrm{ng} / \mathrm{ml})$ for $72 \mathrm{~h}$. Cells were initially stained with anti- $\alpha$-SMA antibody conjugated to FITC and then repeat staining performed using an anti-COLI antibody and a secondary antibody conjugated to TxRed. Another experiment was performed following addition of 400 Muf NTU 283 inhibitor. Magnification 400X.
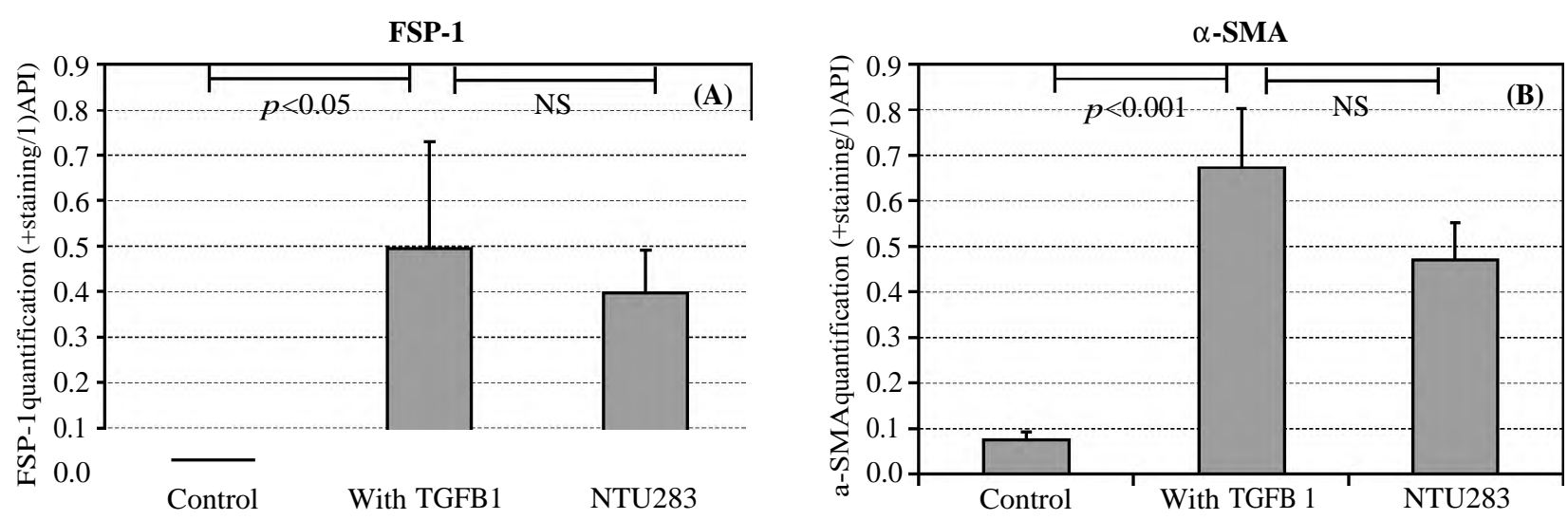

COLI
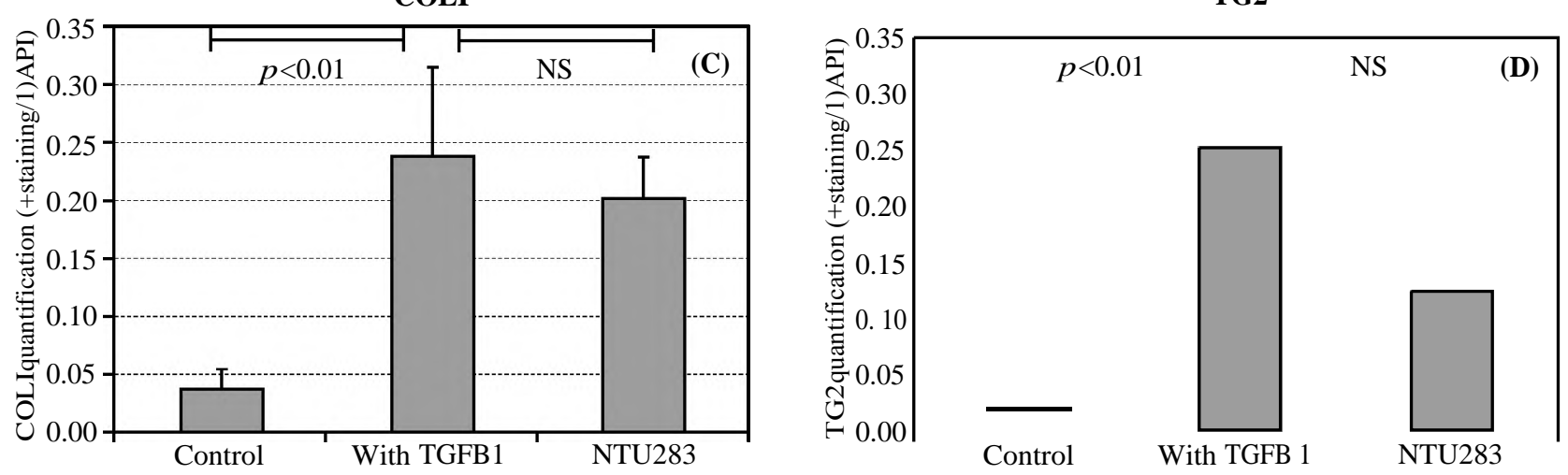

Fig. (5): Quantification of FSP-1, $\alpha$-SMA, COLI and TG2. Phase analysis was used for quantification in control cells, cells induced with $10 \mathrm{ng} / \mathrm{ml}$ TGF- $\beta 1$ for $72 \mathrm{~h}$ and following addition of 400 Mof NTU 283 inhibitor. 

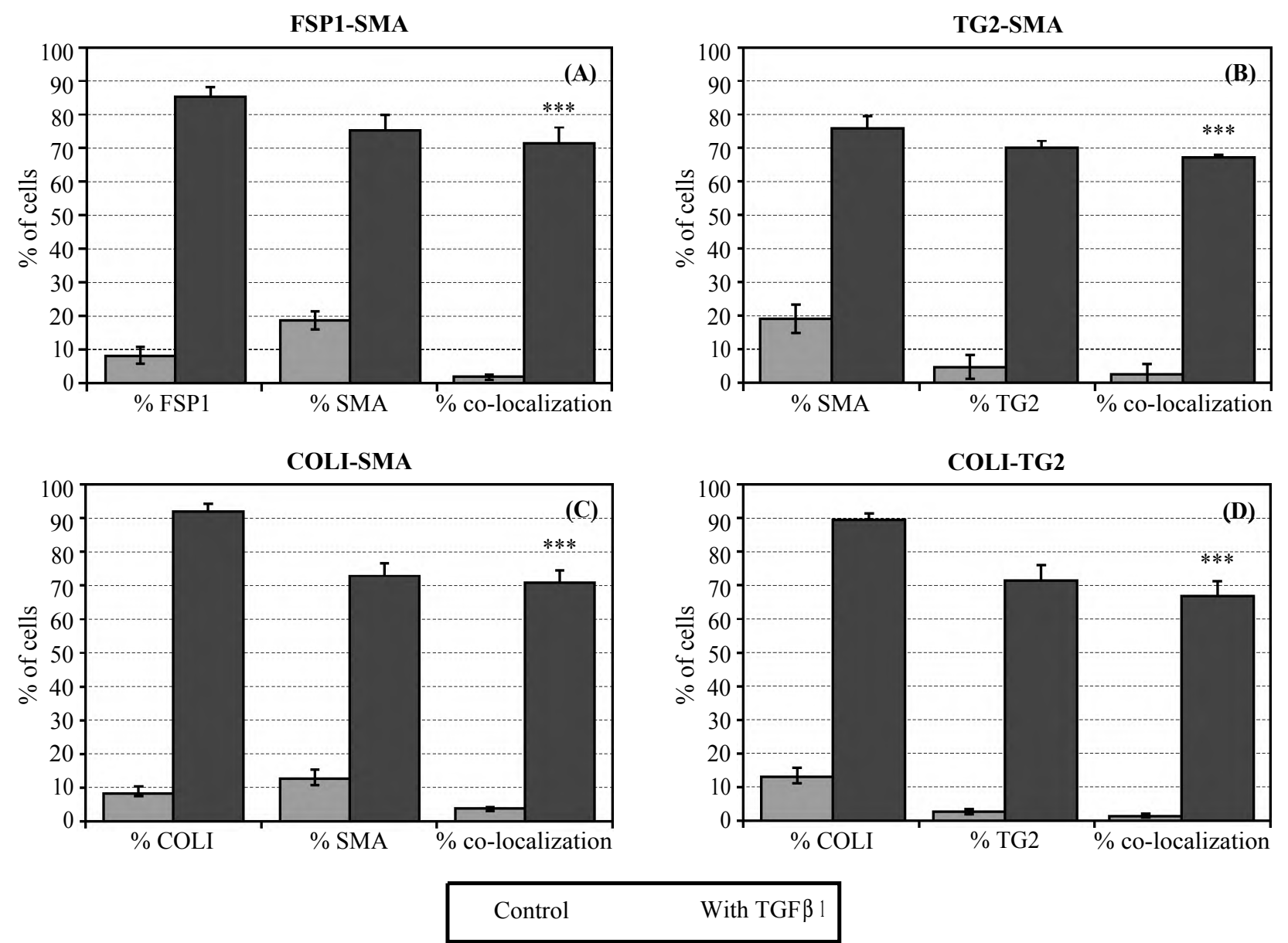

Fig. (6): Estimation of co-localisation of cells following TGF- $\beta$ induction. Co-localisation was expressed as percentage of cells relative to the total number of cells.

\section{Discussion}

EMT and extracellular matrix deposition are both crucial in the course of renal fibrosis. In this piece of work, we investigated the effect of induction of rat kidney cells with TGF- $\beta$ and the link to TG2 expression and activity. In our experiments, NRK52E cells induced with TGF- $\beta$ over $72 \mathrm{~h}$ demonstrated characteristics associated with the EMT phenotype i.e. change in cell morphology, losing the characteristic tubular shape. This was associated with cells loss of epithelial marker E-Cadherin and acquisition of the fibroblast cell markers $\alpha$-SMA and FSP-1; which are typical features of epithelial mesenchymal transdifferentiation.

FSP-1 is a fibroblast-specific protein and is expressed by tubular epithelial cells that undergo EMT [14]. Therefore, one of the markers of fibroblast formation is the expression of FSP1 [15]. Our work showed that induction with TGF- $\beta$ revealed increase of FSP-1 considerably, in comparison to control. Dual staining revealed that FSP1 colocalized with $\alpha$-SMA in more than $68 \%$ of the total cells.
Immunoflourescence staining of TGF- $\beta$ induced cells showed over ten times increase in the amount of TG2 relative to control. Dual staining indicated that cells with high TG2 levels demonstrated loss of epithelial phenotype, but gained fibroblast characteristic marker $\alpha$-SMA. More than $70 \%$ of the total cells showed co-localization of TG2 and $\alpha$ SMA. This established that cells overexpressing TG2 were exclusively $\alpha$-SMA positive confirming a direct association between changes in TG2 and the development of an EMT phenotype. Cells also demonstrated co-localization of TG2 with collagen I which was found to be highly significant. A significant increase in TG2 activity and protein expression could be detected with TGF- $\beta$ 1-induced cells, even at 24 and $48 \mathrm{~h}$. This correlated with the loss of E-Cadherin and increase in $\alpha$-SMA, FSP1 and Col-I.

On the other hand, cells treated with TG2 inhibitor (NTU283) were investigated for any changes in EMT. Although NTU283 resulted in a nonsignificant inhibition, the TG2 inhibitor could ameliorate the induction of EMT, with most of 
$\alpha$-SMA lost the typical fibril structure and change the pattern of collagen I co-localization. This might denote that TG2 mediated changes may not be reversible. Change in staining pattern of $\alpha$-SMA and COLI after inhibitor treatment with loss of the homogenous distribution and fibrillary pattern might reflect some inhibitory effect on TG2 biological activities. Our data western blots showing increased TG2 expression and activity assays with Increased transglutaminase activity was parallel to the increase in mesenchymal cell markers $\alpha$ SMA, COL I and FSP-1 and their co-localisation. This confirms the strong association between TG2 and EMT. In contrast, Yamaguchi et al., (2017) confirmed that Transglutaminase 2 upregulated in primary hepatocellular carcinoma, but suggested that TG2 might contribute to early HCC recurrence through signalling pathways not related to EMT and integrin signalling [16]

Role of TG2 in EMT was extensively studied in cancer biology but to a less extent in the context of renal EMT. Using mammary epithelial cell lines, Kumar and colleagues were able to demonstrate the important role of TG2 in promoting EMT [8] TG2-induced EMT was also observed in ovarian cancer cells [17]. Consistently, TG2 was shown to activate NF- $\kappa \mathrm{B}$ in the mouse RCC cell line RenCa, resulting in the subsequent induction of EMT, in a GTP-binding manner [18] . elevated TG2 expression has been strongly associated with RCC progression in terms of cell survival, invasion and migration [11]. Upregulation of TG2 in NRK52E renal tubular epithelial cell line in conjunction with increased TG2 activity in our work is consistent with these findings.

TG2 is also known to enhance $\beta$-catenin transcriptional activity and the latter is important in cell-cell junction complexes by attaching to Cadherins [19]. Cell-cell junction disruption is an important step in the course of EMT. TG2 switching of E-cadherin to $\mathrm{N}$-cadherin is another proposed mechanism in the course of TGF- $\beta$ induced EMT [20]. Loss of epithelial cell marker E Cadherin was evident in our results.

Inhibition experiments using TG2 inhibitor (NTU283) were investigated for any changes in EMT. This resulted in a non-significant inhibition, but demonstrated clear changes in cells morphology and co-localisation. This might denote that TG2 mediated changes may not be reversible. TG2 expression correlated with tumour advancement and expression of markers of epithelialmesenchymal transition in colorectal cancer patients
[21]. However, in contrast to our results, TG2 knockdown or inhibition reversed EMT.

The existing controversy on the role of TG2 in cancer progression makes it difficult to develop efficient therapeutic strategies. Whether TG2 acts as a tumour suppressor or oncoprotein seems to depend on the cell type and context [22]. Taken altogether, our findings confirm the role of TG2 in renal EMT in vitro. However, further research need to be performed to further clarify and define the exact actions of TG2 in this process.

\section{References}

1- ZEISBERG M. and KALLURI R.: The role of epithelialto-mesenchymal transition in renal fibrosis. J. Mol. Med. (Berl), 82 (3): 175-81, 2004.

2- GRANDE M., FRANZEN A., KARLSSON J.O., ERICSON L.E., HELDIN N.E. and NILSSON M.: Transforming growth factor-beta and epidermal growth factor synergistically stimulate Epithelial to Mesenchymal Transition (EMT) through a MEK-dependent mechanism in primary cultured pig thyrocytes. J. Cell Sci., 115 (Pt 22): 4227 36, 2002.

3- WILLIS B.C. and BOROK Z.: TGF-beta-induced EMT: Mechanisms and implications for fibrotic lung disease. Am. J. Physiol. Lung. Cell Mol. Physiol., 293 (3): L52534, 2007.

4- BORDER W.A. and NOBLE N.A.: Cytokines in kidney disease: The role of transforming growth factor-beta. American journal of kidney diseases: The Official Journal of the National Kidney Foundation, 22 (1): 105-13, 1993.

5- NURMINSKAYA M.V. and BELKIN A.M.: Cellular functions of tissue transglutaminase. Int. Rev. Cell Mol. Biol., 294: 1-97, 2012.

6- ERDEM S., YEGEN G., TELCI D., YILDIZ I., TEFIK T., ISSEVER H., et al.: The increased transglutaminase 2 expression levels during initial tumorigenesis predict increased risk of metastasis and decreased disease-free and cancer-specific survivals in renal cell carcinoma. World J. Urol., 33 (10): 1553-60, 2015.

7- KANG K.T., KWON Y.W., KIM D.K., LEE S.I., KIM K.H., SUH D.S., et al.: TRRAP stimulates the tumorigenic potential of ovarian cancer stem cells. B.M.B. Rep., 51 (10): 514-9, 2018.

8- KUMAR A., XU J., BRADY S., GAO H., YU D., REUBEN J., et al.: Tissue transglutaminase promotes drug resistance and invasion by inducing mesenchymal transition in mammary epithelial cells. PLoS One, 5 (10): e13390, 2010.

9- SHWEKE N., BOULOS N., JOUANNEAU C., VANDERMEERSCH S., MELINO G., DUSSAULE J.C., et al.: Tissue transglutaminase contributes to interstitial renal fibrosis by favoring accumulation of fibrillar collagen through TGF-beta activation and cell infiltration. Am. J. Pathol., 173 (3): 631-42, 2008.

10-NUNES I., GLEIZES P.E., METZ C.N. and RIFKIN D.B.: Latent transforming growth factor-beta binding protein domains involved in activation and transglutaminase- 
dependent cross-linking of latent transforming growth factor-beta. J. Cell Biol., 136 (5): 1151-63, 1997.

11- BAGATUR Y., ILTER AKULKE A.Z., BIHORAC A., ERDEM M. and TELCI D.: Tissue transglutaminase expression is necessary for adhesion, metastatic potential and cancer stemness of renal cell carcinoma. Cell Adh. Migr., 12 (2): 138-51, 2018.

12- NYABAM S., WANG Z., THIBAULT T., OLUSEYI A., BASAR R., MARSHALL L., et al.: A novel regulatory role for tissue transglutaminase in epithelial-mesenchymal transition in cystic fibrosis. Biochim. Biophys. Acta., 1863 (9): 2234-44, 2016.

13- JOHNSON T.S., GRIFFIN M., THOMAS G.L., SKILL J., COX A., YANG B., et al.: The role of transglutaminase in the rat subtotal nephrectomy model of renal fibrosis. J. Clin. Invest., 99 (12): 2950-60, 1997.

14- IWANO M., PLIETH D., DANOFF T.M., XUE C., OKADA H. and NEILSON E.G.: Evidence that fibroblasts derive from epithelium during tissue fibrosis. J. Clin. Invest., 110 (3): 341-50, 2002.

15- OKADA H., DANOFF T.M., KALLURI R. and NEILSON E.G.: Early role of Fsp1 in epithelial-mesenchymal transformation. The American Journal of Physiology, 273 (4 Pt 2): F563-74, 1997.

16- YAMAGUCHI H., KURODA K., SUGITANI M., TAKAYAMA T., HASEGAWA K. and ESUMI M.: Transglutaminase 2 is upregulated in primary hepatocellular carcinoma with early recurrence as determined by proteomic profiles. Int. J. Oncol., 50 (5): 1749-59, 2017.

17- SHAO M., CAO L., SHEN C., SATPATHY M., CHELLADURAI B., BIGSBY R.M., et al.: Epithelial-tomesenchymal transition and ovarian tumor progression induced by tissue transglutaminase. Cancer Res., 69 (24): 9192-201, 2009.

18- KUMAR A., XU J., SUNG B., KUMAR S., YU D., AGGARWAL B.B., et al.: Evidence that GTP-binding domain but not catalytic domain of transglutaminase 2 is essential for epithelial-to-mesenchymal transition in mammary epithelial cells. Breast Cancer Res., 14 (1): R4, 2002.

19- CONDELLO S., CAO L. and MATEI D.: Tissue transglutaminase regulates beta-catenin signaling through a cSrc-dependent mechanism. FASEB J., 27 (8): 3100-12, 2013.

20- PARK Y.M., YOO S.H. and KIM S.H.: Adipose-derived stem cells induced EMT-like changes in H358 lung cancer cells. Anticancer. Res., 33 (10): 4421-30, 2013.

21- AYINDE O., WANG Z. and GRIFFIN M.: Tissue transglutaminase induces Epithelial-Mesenchymal-Transition and the acquisition of stem cell like characteristics in colorectal cancer cells. Oncotarget., 8 (12): 20025-41, 2017.

22- NEZIR A.E., ULUKAN B. and TELCI D.: Transglutaminase 2: The Maestro of the Oncogenic Mediators in Renal Cell Carcinoma. Med. Sci. (Basel), 7 (2), 2019. 


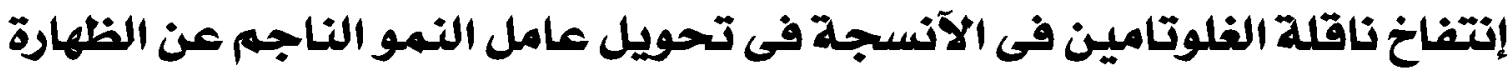

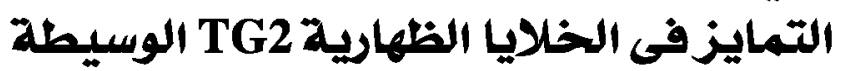

خلفيه: من الإعتقاد العائد آن تحل الخلايا الآنبوبية إلى الخلايا الظهارية الوبيطة هى خطوة رئيسية فى تحديد مسار التيف الكبيبى والمؤدى إلى فثل الكلى.

لقد تم بالفعل تصديد العديد من العوامل المنظمة لهذه العملية. ويلعب التجى آف بيتا دوراً مركزياً. لإنزيم الناقل النسيجى دوراً حاسماً فى خطوة تكوين وإستقرار مصفوفة النسيج الخارجي.

الغرض من البحث: لقد صممت هذه الدراسة لإستكثاف ما إذا كان لهذا الإنزيم دوراً حيوياً فى تحفيز تصل الخلايا الآنبوبية الظهارية

طريقة العهل: تم تحقيق التحول الآنبوبى الظهارى بمعالجة خلايا الكلى الآنبوبية بتركيز عالي من بروتين تجى آف بيتا لمدد عY ومع وY سباعة على التوالى.

تم التحقق من تمام التحل الخلوى بإستكثاف ظهود دلالات خلوية محددة، هي الروتين محدد الليفية، وبروتين آلفا للعضلات الملساء، وكذالك بالكثف عن إنخفاض آلفا كادهيرين.

إستخدمت مثبطات التجى تو فى تجارب فحص التبيط. كما تم القياس الكمى لنشاط التجى تو بواسطة تجارى قياس البوتريسين.

ولتمديد مقدار إفراز البرتين ومكانه، إستخدمنا قياس التوطين وصبغات القياس المناعى المزدوج لكل من الدلالات المستعملة.

النتائج: تم رصد زيادة فى النشاط الحيوى ومقدار إفراز بروتين التجى تو على حد سواء بعد إستحثاث التحل الخلوى لمدة ^ع سـاعة.

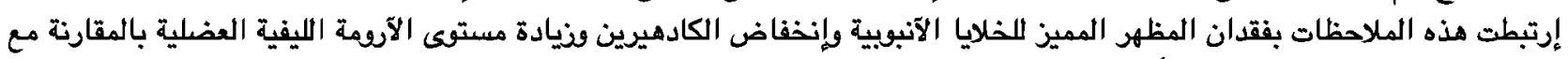
الطبيعى، كما آظهرت الخلايا إرتفاعاً في نسبة الفيطات الكرلاجين.

خاتمة: آوضحت هذه البيانات آن إنزيم التجى تو يساعد بشكل قوى على إستحثاث عملية تحول الخلايا الآنبويية الظهارية، كما آظهرت

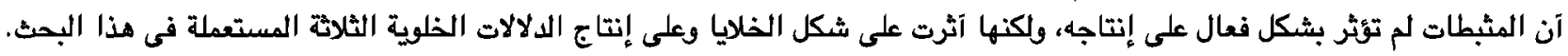

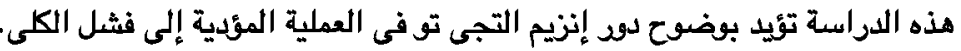

